\title{
Effect of Hatching Eggs Injection with Inactivated Newcastle Disease Vaccine and Two Doses of Cod Liver Oil on some Productive Traits and Immune Response of Broilers
}

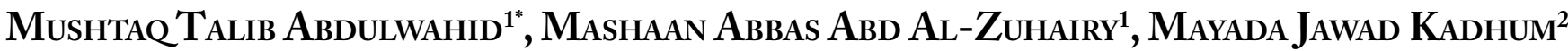

\begin{abstract}
${ }^{1}$ Department of Veterinary Public Health, College of Veterinary Medicine, Baghdad University, Iraq; ${ }^{2}$ Department of Biology and Medicine Supervision/Veterinary Directorate, Iraq.
\end{abstract}

\begin{abstract}
This study was aimed to evaluate the influence of injection of hatching eggs with inactivated Newcastle disease vaccine (ND) and two doses of Cod liver oil (CLO) on hatchability, some biochemical, productive traits and immune response of broiler chickens. Two hundred fertilized eggs of broiler breeders Ross 308 strain were incubated in automatic incubator machine. They were divided into four groups (50 eggs per group) with two replicates. The first group was injected in amniotic fluid with $0.1 \mathrm{ml}$ of Phosphate Buffer Saline (PBS) /egg which was considered as control, the second group was injected with $0.1 \mathrm{ml}$ of inactivated oil emulsified ND vaccine /egg, the third group was injected with $0.1 \mathrm{ml}$ of inactivated oil emulsified ND vaccine and $0.1 \mathrm{ml}$ of CLO /egg, the fourth group was injected with $0.1 \mathrm{ml}$ of inactivated oil emulsified ND vaccine and $0.15 \mathrm{ml}$ of CLO/egg. The eggs were returned to incubator till hatching date. Hatched chicks were reared in the hall of the Veterinary Medicine College/University of Baghdad after distributed into four groups with two replicates according to the previously treated groups until the fifth week of age. The results showed a significant $(P \leq 0.05)$ increased of the treated groups in hatchability, body weight and improvement in feed conversion ratio as compared with second group and control, also fourth group showed significantly increased $(\mathrm{P} \leq 0.05)$ in antibody titers against $\mathrm{ND}$ virus at age of 21 and 35 day as compared with the other treated groups and control.
\end{abstract}

Keywords | In ovo injection, Cod liver oil, Immune response, Newcastle, Broiler

Editor | Kuldeep Dhama, Indian Veterinary Research Institute, Uttar Pradesh, India.

Received | January 13, 2017; Accepted | February 16, 2017; Published | February 28, 2017

*Correspondence | Mushtaq Talib Abdulwahid, Department of Veterinary Public Health, College of Veterinary Medicine, Baghdad University, Iraq; Email: dr.m.t.abdulwahid@gmail.com

Citation | Abdulwahid MT, Al-Zuhairy MAA, Kadhum MJ (2017). Effect of hatching eggs injection with inactivated newcastle disease vaccine and two doses of cod liver oil on some productive traits and immune response of broilers. Adv. Anim. Vet. Sci. 5(2): 100-106.

DOI | http://dx.doi.org/10.14737/journal.aavs/2017/5.2.100.106

ISSN (Online) | 2307-8316; ISSN (Print) | 2309-3331

Copyright (C) 2017 Abdulwahid et al. This is an open access article distributed under the Creative Commons Attribution License, which permits unrestricted use, distribution, and reproduction in any medium, provided the original work is properly cited.

\section{INTRODUCTION}

$\mathrm{T}$ he production of hatching eggs that will provide strong viable chicks is a key factor in the successful propagation of poultry, the nutrition of the breeding hen is one of the most factors important in these situations (Koreleski and Switakiewicz, 2006; Yegani, and Korver, 2008). The egg must contain all the nutrients needed by the embryo when it is laid by the hen. Nutrient deficiencies can cause marked reduction in hatchability and often malformed embryos grow as a result of the nutrient deficiency (less supply of energy, less supply of some vitamins and minerals) responsible for poor hatchability by examination of the embryo (Uni et al., 2005). About 5-6 gm of lipid found in the yolk of the egg, nearly $80 \%$ of it was absorbed by the embryo for energy production and structural membrane synthesis. Lipid peroxidation of low quality fat may predispose the embryo to increase metabolic disorder and damage to cellular membranes (Noble and Cocchi, 1990). Fat sources are essential to fuel the heart and for the deposition of polyunsaturated fatty acids (PUFA) in tissues such as the brain as important roles in energy production for the embryo (Cherian and Sim, 1992). Thus, the additional energy source supported the late-term embryos and improve early growth to enhance the genetic potential for late embryonic and early post hatch growth (Uni and 
Ferket, 2004; Al-Daraji et al., 2010b) and help chicks to enhance ability of digestion and metabolism after hatching which led to improving the productive traits and accelerate access to marketing weight (Dos Santos et al., 2010; Selim et al., 2012). Cod liver oil is a source of omega-3 essential fatty acids (Eicosapentaenoic acid EPA and decosahexaenoic acid DHA) (Guillen et al., 2008). In ovo administration of high quality polyunsaturated fatty acids such as Cod liver oil may improve energy during embryogenesis and hatching process, also, are important constituents of the immune cell structure with great physiological effects in birds, as well as, increase poultry productivity (Heird and Lapillonne, 2005; Shaikh and Edidin, 2006; Chang et al., 2010; Abdulwahid and Al-Zuhairy, 2013). The objective of this study to find out the impact in ovo administration with inactivated ND vaccine and two doses of Cod liver oil on hatchability, some physiological, productive traits and immune response of broiler.

\section{MATERIALS AND METHODS}

This study includes two stages; the first stage was the incubation period for fertilized eggs which was carried out at automated incubator after graded and culled the abnormal and misshapen. Two hundred fertilized eggs of Ross 308 broiler breeders were distributed into four groups; fifty fertilized eggs were assigned to each group, the first group (Group 1) was injected with $0.1 \mathrm{ml} / \mathrm{egg}$ of Phosphate Buffer Saline (PBS) into amniotic fluid at day $18^{\text {th }}$ of incubation which was considered as a control, the second group (Group 2) was injected with $0.1 \mathrm{ml} / \mathrm{egg}$ of inactivated oil emulsified ND vaccine, the third group was injected with $0.1 \mathrm{ml} /$ egg of inactivated oil emulsified ND vaccine and 0.1 $\mathrm{ml} / \mathrm{egg}$ of Cod liver oil (CLO) and the fourth group was injected with $0.1 \mathrm{ml} / \mathrm{egg}$ of inactivated oil emulsified ND vaccine and $0.15 \mathrm{ml} / \mathrm{egg}$ of CLO. Handel egg injection method applied for injection of CLO and ND vaccine after candled and only embryonated eggs selected for injection. Complete disinfection was done after every injection by alcohol $70 \%$ to prevent cross contamination between individual eggs. Injection depth was $2.5 \mathrm{~cm}$ from the broad end. After the eggs were injected, the injection holes were sealed with sterile wax and return to the incubator for complete hatching process, maintained in the biology and medicine supervision Department/Veterinary Directorate (Iraq). The second stage was started when hatched chicks were transported to the poultry farm of Veterinary College /Baghdad University and then distributed into four groups (with two replicates of each group) depending on the previously treated groups up to end of the study. The hall ground was covered with suitable litter (softwood shaving) after cleaning the floor, wall and ceiling and other factors like lighting and ventilation were controlled according to recommendations. All chicks of treated groups were given ad libitum access to feed and water.
The diet was formulated according to the recommendations of (NRC, 1994). The chicks were given the starter diet for the two weeks (starter period), then after, it fed grower diet for the end of the study. All chicks of this study were vaccinated with $0.03 \mathrm{ml} /$ chick of attenuated ND IB (Volvac ${ }^{\circ}$ ) at 7 days old via the ocular route. Cod Liver Oil (CLO) was used in ovo injection produced by Vitex Pharmaceuticals Pty Ltd-Australia. Also, the vaccine was used in this study was Volvac ${ }^{\oplus}$ ND KV (Boehringer Ingelheim-HQ Germany) inactivated oil emulsified vaccine elaborated with ND virus, LaSota strain. Each $0.5 \mathrm{ml}$ contains a minimum titer: $10^{8.2} \mathrm{EID}_{50} /$ dose of ND before inactivation. A total of 40 blood samples (10 samples per group) were taken randomly from the wing vein, after coagulation, the blood was centrifuged at $2500 \mathrm{rpm}$ for 5 minutes to obtain the serum. The serum samples were frozen at $\left(-20^{\circ} \mathrm{C}\right)$ until analyzed for biochemical parameters changes and ELISA test at day $35^{\text {th }}$ of birds age (Allan, 1978).

The concentrations of total serum protein, Albumin, Globulin, Cholesterol, Triglyceride and High Density Lipoprotein (HDL) were measured with the use of spectrophotometer by commercial enzymatic Kits (BioSystems S.A. company /Spain) according to (Wotton, 1964; Fossati and Prencipe, 1982). Productive traits represented by (body weight, weight gain, feed intake and feed conversion ratio) were determined each week until five weeks. The antibody $(\mathrm{Ab})$ titers against ND virus in chicks serum samples were detected at (7,21 and 35) days of age by using ELISA test for different groups. ND virus antibody test kit ProFLOK ${ }^{\circledast}$ PLUS Synbiotics Corporation -San Diego/USA was used in this study.

\section{Statistical Analysis}

All data were submitted to statistical analysis by analysis of variance (ANOVA) (Snedecor and Cochran, 1980) by using SPSS program (SPSS, 1999). The least significant differences (L.S.D) were used to assess the differences the mean. $\mathrm{P} \leq 0.05$ considered significant.

\section{RESULTS}

The data of Table 1 showed that hatchability $\%$ and weights of newly hatching chicks were significantly $(\mathrm{P} \leq 0.05)$ increased in groups $3^{\text {rd }}$ and $4^{\text {th }}$ as compared with the $2^{\text {nd }}$ and control, while, there were no significant $(\mathrm{P}>0.05)$ differences between the groups $3^{\text {rd }}$ and $4^{\text {th }}$ in these traits. Also, the results showed significant $(\mathrm{P} \leq 0.05)$ increases in mean body weight and body weight gain of third and fourth groups as compared with the second group and control in $\left(3^{\text {rd }}, 4^{\text {th }}\right.$ and $\left.5^{\text {th }}\right)$ weeks. As well as, the mean body weight of the fourth group was increased significantly $(\mathrm{P} \leq 0.05)$ more than other groups and control in weeks ( $4^{\text {th }}$ and $\left.5^{\text {th }}\right)$. Although there were no significant $(P>0.05)$ differences 
Table 1: Hatchability, body weight, body weight gain, feed intake and feed conversion ratio for different groups (Mean $\pm \mathrm{SE})$

\begin{tabular}{|c|c|c|c|c|c|c|c|c|c|}
\hline \multicolumn{2}{|l|}{ Groups } & \multicolumn{2}{|c|}{ First group (Control) } & \multirow{2}{*}{\multicolumn{2}{|c|}{ Second group }} & \multicolumn{2}{|l|}{ Third group } & \multirow{2}{*}{\multicolumn{2}{|c|}{ Fourth group }} \\
\hline \multirow{2}{*}{\multicolumn{2}{|c|}{$\begin{array}{l}\text { Variables Age } \\
\text { Hatchability\% }\end{array}$}} & & & & & & & & \\
\hline & & $83.3 \pm 0.577$ & $\mathrm{C}$ & $86.6 \pm 1.154$ & B & $93.3 \pm 1.154$ & A & $93.3 \pm 1.732$ & A \\
\hline \multirow{4}{*}{$\begin{array}{l}\text { Body } \\
\text { weight } \\
\text { (gm) }\end{array}$} & $1^{\text {st }}$ day & $44.72 \pm 0.56$ & B & $44.78 \pm 0.52$ & B & $45.92 \pm 0.63$ & A & $46.66 \pm 0.41$ & A \\
\hline & $1^{\text {st }} \mathrm{wk}$ & $107.2 \pm 0.72$ & & $106.8 \pm 0.41$ & & $110.7 \pm 0.75$ & & $111.1 \pm 0.77$ & \\
\hline & $2^{\text {nd }} \mathrm{wk}$ & $274.9 \pm 1.89$ & & $273.7 \pm 1.80$ & & $273.2 \pm 1.24$ & & $271.2 \pm 1.03$ & \\
\hline & $3^{\text {rd }} \mathrm{wk}$ & $595.5 \pm 2.10$ & B & $590.2 \pm 2.85$ & B & $613.6 \pm 1.36$ & A & $605.5 \pm 1.58$ & A \\
\hline \multirow{7}{*}{$\begin{array}{l}\text { Body } \\
\text { weight gain } \\
\text { (gm) }\end{array}$} & $4^{\text {th }} \mathrm{wk}$ & $1162.8 \pm 9.46$ & $\mathrm{C}$ & $1162.8 \pm 9.46$ & $\mathrm{C}$ & $1230.8 \pm 4.95$ & $\mathrm{~B}$ & $1241.0 \pm 3.11$ & A \\
\hline & $5^{\text {th }} \mathrm{wk}$ & $1713.0 \pm 4.15$ & $\mathrm{C}$ & $1758.8 \pm 5.28$ & $\mathrm{C}$ & $1851.1 \pm 3.57$ & B & $1861.2 \pm 1.62$ & A \\
\hline & $1^{\text {st }} \mathrm{wk}$ & $62.50 \pm 0.10$ & & $62.10 \pm 0.08$ & & $64.80 \pm 0.10$ & & $64.50 \pm 0.11$ & \\
\hline & $2^{\text {nd }} \mathrm{wk}$ & $167.7 \pm 0.84$ & A & $166.9 \pm 1.11$ & B & $162.5 \pm 1.43$ & B & $160.1 \pm 1.22$ & $\mathrm{~B}$ \\
\hline & $3^{\text {rd }} \mathrm{wk}$ & $321.3 \pm 1.44$ & $\mathrm{~B}$ & $317.0 \pm 2.57$ & B & $340.3 \pm 4.62$ & $\mathrm{~A}$ & $334.2 \pm 2.88$ & $\mathrm{~A}$ \\
\hline & $4^{\text {th }} \mathrm{wk}$ & $587.3 \pm 2.63$ & $\mathrm{C}$ & $587.8 \pm 6.73$ & $\mathrm{C}$ & $617.2 \pm 2.17$ & $\mathrm{~B}$ & $635.5 \pm 2.14$ & A \\
\hline & $5^{\text {th }} \mathrm{wk}$ & $550.2 \pm 7.41$ & $\mathrm{C}$ & $580.2 \pm 2.59$ & $\mathrm{~B}$ & $620.3 \pm 2.01$ & A & $620.2 \pm 1.28$ & A \\
\hline \multirow{5}{*}{$\begin{array}{l}\text { Feed intake } \\
\text { (gm) }\end{array}$} & $1^{\text {st }} \mathrm{wk}$ & $156.2 \pm 0.75$ & & $155.4 \pm 0.60$ & & $154.7 \pm 0.30$ & & $151.6 \pm 1.65$ & \\
\hline & $2^{\text {nd }} \mathrm{wk}$ & $369.1 \pm 0.90$ & A & $362.9 \pm 2.95$ & A & $342.5 \pm 2.45$ & $\mathrm{~B}$ & $337.2 \pm 1.75$ & B \\
\hline & $3^{\text {rd }} w k$ & $663.1 \pm 3.85$ & A & $660.8 \pm 2.15$ & $\mathrm{AB}$ & $658.7 \pm 1.30$ & $\mathrm{AB}$ & $653.4 \pm 3.40$ & B \\
\hline & $4^{\text {th }} \mathrm{wk}$ & $1217.8 \pm 2.85$ & $\mathrm{AB}$ & $1212.6 \pm 2.15$ & $\mathrm{~B}$ & $1220.3 \pm 5.30$ & A & $1202.6 \pm 2.35$ & $\mathrm{C}$ \\
\hline & $5^{\text {th }} \mathrm{wk}$ & $1232.8 \pm 2.85$ & $\mathrm{~B}$ & $1243.7 \pm 1.25$ & A & $1207.6 \pm 2.65$ & $\mathrm{C}$ & $1196.8 \pm 1.80$ & $\mathrm{D}$ \\
\hline \multirow{5}{*}{$\begin{array}{l}\text { Feed } \\
\text { conversion } \\
\text { ratio }\end{array}$} & $1^{\text {st }} \mathrm{wk}$ & $2.48 \pm 0.04$ & A & $2.49 \pm 0.04$ & A & $2.38 \pm 0.04$ & B & $2.37 \pm 0.05$ & B \\
\hline & $2^{\text {nd }} \mathrm{wk}$ & $2.19 \pm 0.10$ & A & $2.19 \pm 0.04$ & A & $2.09 \pm 0.01$ & B & $2.09 \pm 0.01$ & B \\
\hline & $3^{\text {rd }} \mathrm{wk}$ & $2.05 \pm 0.07$ & A & $2.07 \pm 0.05$ & A & $1.93 \pm 0.06$ & B & $1.96 \pm 0.01$ & B \\
\hline & $4^{\text {th }} \mathrm{wk}$ & $2.15 \pm 0.05$ & A & $2.06 \pm 0.01$ & B & $1.98 \pm 0.07$ & $\mathrm{C}$ & $1.88 \pm 0.04$ & $\mathrm{D}$ \\
\hline & $5^{\text {th }} \mathrm{wk}$ & $2.24 \pm 0.01$ & A & $2.14 \pm 0.07$ & B & $1.95 \pm 0.04$ & $\mathrm{C}$ & $1.93 \pm 0.03$ & $\mathrm{C}$ \\
\hline
\end{tabular}

Different large letters horizontally refer to significant differences at level $(\mathrm{P} \leq 0.05)$ among mean of groups

Table 2: Biochemical parameters for different groups at 35 days old (Mean \pm SE)

\begin{tabular}{|c|c|c|c|c|c|}
\hline Parameters & First group (Control) & Second group & Third group & & Fourth group \\
\hline Total Protein (gm/L) & $48.67 \pm 0.185 \quad \mathrm{D}$ & $52.45 \pm 0.117 \mathrm{C}$ & $56.81 \pm 0.157$ & B & $58.74 \pm 0.139 \mathrm{~A}$ \\
\hline Albumin $(\mathrm{gm} / \mathrm{L})$ & $23.46 \pm 0.181 \quad A$ & $23.97 \pm 0.092 \quad B$ & $20.39 \pm 0.168$ & $\mathrm{C}$ & $20.51 \pm 0.125 \mathrm{C}$ \\
\hline Globulin (gm/L) & $25.21 \pm 0.052 \quad \mathrm{D}$ & $28.47 \pm 0.081 \mathrm{C}$ & $36.41 \pm 0.058$ & $\mathrm{~B}$ & $38.22 \pm 0.0 .32 \quad \mathrm{~A}$ \\
\hline Total Cholesterol (mg/dl) & $179.97 \pm 0.532 \quad \mathrm{~A}$ & $178.30 \pm 0.382 \quad B$ & $160.70 \pm 0.505$ & $\mathrm{C}$ & $153.74 \pm 0.526 \mathrm{D}$ \\
\hline Triglycerides (mg/dl) & $120.66 \pm 0.810 \quad \mathrm{~A}$ & $120.39 \pm 1.132 \mathrm{~A}$ & $102.99 \pm 1.299$ & $\mathrm{~B}$ & $99.66 \pm 1.219 \quad \mathrm{~B}$ \\
\hline HDL-Cholesterol mg/dl) & $26.22 \pm 0.276 \quad C$ & $25.21 \pm 0.332 \quad \mathrm{D}$ & $27.94 \pm 0.191$ & $\mathrm{~B}$ & $29.40 \pm 0.187 \quad \mathrm{~A}$ \\
\hline
\end{tabular}

Different large letters horizontally refer to significant differences at level $(\mathrm{P} \leq 0.05)$ among mean of groups

between the third and fourth groups in body weight gain at the $3^{\text {rd }}$ and $5^{\text {th }}$ week. The fourth group was $(\mathrm{P} \leq 0.05)$ the second and third groups and control in the 4 th week. The third and fourth groups were recorded significant $(\mathrm{P} \leq 0.05)$ decreases in feed intake and improvement in feed conversion efficiency in the 5 th week as compared with the second and control; also the fourth group was recorded significant $(\mathrm{P} \leq 0.05)$ reduces values in feed intake as compared with the third group and other groups at $5^{\text {th }}$ week. As well as, data of the same table indicated that significantly $(\mathrm{P} \leq 0.05)$ improvement in feed conversion efficiency of third and fourth groups as compared with the second group and control up to the end of this in the study.

According to data of Table 2, the results showed that total protein concentration of the fourth group at (35) days of age significantly $(\mathrm{P} \leq 0.05)$ increased as compared with the other groups and control, as well as, the results illustrated that significant $(P \leq 0.05)$ decreases in albumin onc. and significant $(\mathrm{P} \leq 0.05)$ increases in globulin conc. of the fourth group as compared with the other groups and control. Data of the fourth group showed significant $(\mathrm{P} \leq$ $0.05)$ decrease in cholesterol concentration (153.74 \pm 0.526 $\mathrm{mg} / \mathrm{dL}$ ) as compared with second, third groups and con- 
trol which there were $(178.30 \pm 0.382,160.70 \pm 0.505$ and $179.97 \pm 0.532) \mathrm{mg} / \mathrm{dl}$ respectively.

The analysis of blood triglycerides conc. of the third and the fourth groups were significantly $(\mathrm{P} \leq 0.05)$ lower than the second group and the control, but there were no significant differences $(P>0.05)$ in triglycerides values between the third and the fourth groups. The fourth group mentioned significantly $(\mathrm{P} \leq 0.05)$ higher level in high density lipoprotein (HDL) Cholesterol conc. (29.40 $\pm 0.187 \mathrm{mg} /$ $\mathrm{dL})$ as compared with the second, the third groups and the control $(25.21 \pm 0.332,27.94 \pm 0.191$ and $26.22 \pm 0.276)$ $\mathrm{mg} / \mathrm{dl}$ respectively (Table 2 ).

Although, there were no significant $(\mathrm{P}>0.05)$ differences in $\mathrm{Ab}$ titer against ND virus measured by ELISA among the groups at 7 days old, the data showed significant $(\mathrm{P} \leq$ $0.05)$ higher $\mathrm{Ab}$ titer in blood serum samples of the fourth group than the other groups at 21 and 35 days old (2262.8 \pm 255.30 and $5159.8 \pm 212.76)$ respectively as the illustration shown in (Table 3 ).

Table 3: Antibody titre against ND virus measured by ELISA for different groups (Mean $\pm \mathrm{SE}$ ).

\begin{tabular}{|c|c|c|c|c|}
\hline $\begin{array}{l}\text { Group } \\
\text { Age }\end{array}$ & $\begin{array}{l}\text { First group } \\
\text { (Control) }\end{array}$ & $\begin{array}{l}\text { Second } \\
\text { group }\end{array}$ & Third group & $\begin{array}{l}\text { Fourth } \\
\text { group }\end{array}$ \\
\hline 7 days & $\begin{array}{l}2322.0 \pm \\
152.17\end{array}$ & $\begin{array}{l}2240.0 \pm \\
119.68\end{array}$ & $\begin{array}{l}2320.8 \pm \\
178.94\end{array}$ & $\begin{array}{l}2255.0 \pm \\
142.65\end{array}$ \\
\hline $\begin{array}{l}21 \\
\text { days }\end{array}$ & $\begin{array}{l}1106.0 \pm \\
56.61 \mathrm{C}\end{array}$ & $\begin{array}{l}1947.8 \pm \\
178.71 \\
\text { B }\end{array}$ & $\begin{array}{l}1879.0 \pm \\
236.78 \mathrm{~B}\end{array}$ & $\begin{array}{l}2262.8 \pm \\
255.30 \\
\text { A }\end{array}$ \\
\hline $\begin{array}{l}35 \\
\text { days }\end{array}$ & $\begin{array}{l}812.4 \pm 56.80 \\
\text { D }\end{array}$ & $\begin{array}{l}3193.8 \pm \\
104.34 \\
\mathrm{C}\end{array}$ & $\begin{array}{l}4525.4 \pm \\
72.25 \quad \mathrm{~B}\end{array}$ & $\begin{array}{l}5159.8 \pm \\
212.76 \\
\text { A }\end{array}$ \\
\hline
\end{tabular}

Different large letters horizontally refer to significant differences at level $(\mathrm{P} \leq 0.05)$ among mean of groups.

\section{DISCUSSION}

The increment of hatchability in third and fourth groups might be due to in ovo administration with Cod liver oil (enriched of Omega-3) which improving the energy production during embryogenesis. The results demonstrated that using inoculation with Cod liver oil (CLO) had a significant role in the growth of chicks by increment mean body weight of chicks as compared with control; this could be due to the positive effect of omega- 3 on energy needed by the body for the metabolic process without exhausted of glycogen. Omega -3 PUFAs has importance in the development of the body cells; it enters in the composition of cell membranes (Schaal, 2008). The gastrointestinal tract will be best with Omega -3 PUFAs. Then, digestibility and absorption of necessary nutritional elements were enhanced. Also, fat rich with Omega -3 increased growth due to activating of bile secretion which leads to increase digestion of fats in the intestine and increase the efficiency of digestion and absorption of diets in intestine lumen lead to more useful from diets. The results were obtained are in agreement with the results obtained by (Bou et al., 2004; Safamerher et al., 2008). Furthermore, (Salih, 2009; Tako et al., 2004, Lopes et al., 2006) concluded that in ovo feeding Omega-3 PUFAs were enhanced the muscle growth due to the higher proliferation of myoblasts during embryonic development and to the presence of more satellite cells in early post hatch development. In addition, (Smirnov et al., 2006) revealed that increased of body weight gain and improved feed conversion efficiency when broilers fed diet enriched with Omega-3 PUFAs and 200 $\mathrm{mg}$ vitamin $\mathrm{E} / \mathrm{kg}$ feed as compared with control, they were attributed to the interest of vitamin $\mathrm{E}$ as antioxidant in keeping body tissues from degenerating due to free radicals formation. The results which obtained from the current study were similar to the results of (Basmacioglu et al., 2009) who confirmed that significantly $(P \leq 0.05)$ improvement in feed conversion efficiency of treated chicks with $2 \%$ fish oil during all experimental period (six weeks), they were ascribed to fish oil which enriched of omega-3 unsaturated fatty acid oil (Alparslan and Ozdogan, 2006; Pike, 1999; Saleh et al., 2009) documented that fish oil supplementation at $1.5 \%$ to a diet of chickens significantly improved feed conversion ratio, body weight and daily body weight gain, in addition, the same study observed a significant reduction in feed intake, body weight and average daily body weight gain when the diet was supplemented with the highest level of fish oil (6\%). The results of the current study are in agreement with several studies (Uni and Ferket, 2004; Gore and Qureshi, 1997; Ipek et al., 2004; Kidd et al., 2005; Foye et al., 2006; Moran and JR., 2007; Zhai et al., 2008; Dos Santos et al., 2010; McGruder et al., 2011a) who found that in ovo feeding with various nutrients was enhance the energy status of late term embryos and were improved weights of newly hatching chicks that enhance the genetic potential for late embryonic and early post hatch growth, but the results of the current study disagree with (Schaal, 2008) who showed that in ovo injection of Omega-3 (ALA) was significantly reduced the hatchability due to using ethanol as a carrier to dilute the fatty acids and provide an aqueous solution to embryos. The highest significant increase of total protein and globulin conc. may be due to the role of CLO to improve immunity and increasing of immunoglobulins. The results of the present study were agreement with that of (Al-Mayah, 2009) who found that broilers fed $50 \mathrm{gm}$ of fish oil $/ \mathrm{kg}$ of diet accelerates production of immunoglobulins (IgM and $\mathrm{IgG})$ then increased serum total protein. The increasing in globulin conc. than Albumin conc. may be due to the role of CLO in rising immunity response in the body by stimulating lymphocyte; these results confirmed increasing 
in total protein conc. in blood serum samples of treated chicks with Omega -3 PUFAs (Jaffer, 2010). The results of the treated group which embryonic injection with CLO showed a reduction in cholesterol, triglycerides concentrations and increasing in HDL- cholesterol conc. as compared with untreated groups at 35 days old of chicks. These results could be due to the positive role of CLO which is a rich in Omega-3 unsaturated fatty acid (Roy et al., 2008).

The antioxidant properties of unsaturated fatty acids in CLO should be considered as a major component of its beneficial effects on antioxidant enzyme activities and lipid peroxidation of body tissues, (Hunkar et al., 2002) recorded that CLO play important role in decreasing of plasma cholesterol, triglyceride and it has a protective effect against lipid peroxidation products, by enhancing the antioxidant status.

Sultan (2005) reported that fish oil effect on the cholestlerol conc. is mainly by reduction diverting lipids metaboism to phospholipids formation. Similar results were also observed by (Saleh et al., 2009) in broilers fed diets supplemented with fish oil showed lowered levels of cholesterol and triglyceride conc. in the plasma compared with those fed the control diet.

On the other hand, (Chashnidel et al., 2010) mentioned that broilers dietary fish oil supplementation at percentage $(1.5,3,4.5) \%$ showed a significant decrease in cholesterol and triglycerides conc. in blood serum, this result might be due to reducing of hepatic synthesis by suppressive synthetic enzymes HMG-CoA synthase which enter cholesterol formation and increase $\mathrm{B}$-oxidation process. Omega-3 fatty acids increase the removal of very low density lipoprotein by peripheral tissues or the liver, and increase the excretion of bile in feces which can also reduce the serum concentrations of cholesterol and triglycerides. So, higher omega-3 levels were associated with lower triglycerides and higher HDL-cholesterol, lower LDL cholesterol and total cholesterol (Dewailly et al., 2001; Leaf and Weber, 1988).

The results revealed increased in blood serum HDL-cholesterol of treated birds with embryonic cod liver oil, these led to increase transfers cholesterol molecules from blood and tissues to the liver (Pamela, 2009). Furthermore, the results indicated that CLO elevated HDL-cholesterol receptor activity and promote lipoprotein metabolism by altering the activity and function of certain lipolytic and transferring enzymes in plasma, so dietary omega-3 fatty acids facilitated the transfer of fatty acids from LDL HDL-cholesterol (Roy et al., 2008; Aviram, 2000). The results of the current study suggested that high $\mathrm{Ab}$ titer against ND virus of the treated groups in ovo injected with CLO which improved immune status and lessen in-
Advances in Animal and Veterinary Sciences flammatory conditions. Results of current study also, are in agreement with (Saleh et al., 2009) who explained that supplementation of $3 \%$ fish oil in the diet improved the level of omega-3 PUFAs, then, the positive effect on the immune system were determined, the role of omega-3 fatty acids as immunity stimulators of cytokines and help $\mathrm{B}$-lymphocytes to increase $\mathrm{Ab}$ production. The long chain omega-3 fatty acids (EPA and DHA) have the ability to increase the immune response (Calder, 2001). Despite, the fish oil has shown immunosuppressive at high concentrations and immunostimulatory at lower concentrations when used in chicken diets (Wang et al., 2000).

(Klasing, 1998; Sakr, 2007) considered that omega-3 in fish oil is immune modulator and they recommended to be given after vaccination against Newcastle disease. (Torki et al., 2000) described significant health benefits from diets that include marine fish oil supplements, these benefits include immunological properties such as immunomodulation (Kidd, 2004). Consumption of omega-3 PUSFAs such as CLO markedly modulates the immune and inflammatory response (Kehn and Fernanetes, 2001; Jessica, 2001; Al-Mayah, 2009) explained that chicks fed $50 \mathrm{gm} /$ $\mathrm{kg}$ of diet fish oil were accelerated antibody production and maintained proper immune function after vaccination against ND with LaSota type vaccine at $35^{\text {th }}$ day of age. Several studies demonstrated that chickens fed diets supplemented with lower concentrations of fish oil were improving immune system functions (enhancement the cellular and humoral immunity) (Prickeet, 1982; A1-Khalifa et al., 2012). The diets supplemental with CLO have kept high immune response against Newcastle disease (Aydin, 2007; Zhang et al., 2005).

\section{CONCLUSION}

Our results obtained from this study indicated that in ovo injection with inactivated ND vaccine and different doses of CLO caused enhancement in productive traits and immune response of the hatching chicks. The chicks were treated with $0.15 \mathrm{ml}$ of CLO recorded that significant (P $\leq 0.05$ ) increase in mean body weight at the $4^{\text {th }}$ and $5^{\text {th }}$ week of age with a significant increasing in total protein and decreasing in cholesterol conc. at the $35^{\text {th }}$ day of age, also showed a significant increasing in Ab titer against inactivated ND vaccine at (21 and 35) days of age as compared with other study groups.

\section{ACKNOWLEDGEMENTS}

We are thankful to all staff in Biology and Medicine $\mathrm{Su}^{-}$ pervision Department / Veterinary Directorate for assisted us through carrying out tests of the current study. Also we would like to thank anyone in Veterinary College /Baghdad University who helped us during the study period. 
Chem. Soc. 87: 803-808. https://doi.org/10.1007/s11746010-1555-4

The authors have declared no conflict of interest.

\section{AUTHORS CONTRIBUTION}

All authors contributed equally in constructing the experimental design, analysing data and preparing manuscript.

\section{REFERENCES}

-Abdulwahid MT, Al-Zuhairy MA (2013). Effect of injection the broiler hatching eggs with vitamin $\mathrm{E}$ and cod liver oil on some their productive traits and immune response to Newcastle disease vaccine. Iraqi J. Vet. Med. 37(2): 199 -205.

-A1-Daraji HJ, Al-Mashadani HA, Al-Hayani WK, Mirza HA, Al-Hassani AS (2010b). Effect of dietary supplementation with different oils on productive and reproductive performance of quail. J. Poult. Sci. 9(5):429-435. https://doi. org/10.3923/ijps.2010.429.435

-A1-Khalifa H, Givens DI, Rymer C, Yaqoob P (2012). Effect of n-3 fatty acids on immune function in broiler chickens. Poult. Sci. 91:74-88. https://doi.org/10.3382/ps.201101693

-Allan WH, Lancaster JE, Toth B (1978). Newcastle Disease Vaccines, their Production and Use. Food and Agriculture Organization of the United Nation, Rome.

-Al-Mayah AA (2009). Effect of Fish oil on humoral immunity of broiler chicks, Bas. J. Vet. Res. 8(2).

-Alparslan G, Ozdogan M (2006). The effects of diet containing fish oil on some blood parameters and the performance values of broilers and cost efficiency. Int. J. Poult. Sci. 5: 415419. https://doi.org/10.3923/ijps.2006.415.419

-Aviram M, Dornfeld I, Vokavo N, Kaplan M, Coleman R, Hayek T, Presser D, Fuhrman B (2000). Pomegranate juice consumption reduces oxidative stress, atherogenic modifications to LDL, and platelet aggregation: LDL studies in humans and in atherosclerotic apolipoprotein E-deficient mice. Am. J. Clin. Nutr. 71: 1062-1076.

- Aydin R (2007). Effect of dietary oils and conjugated linoleic acid on the growth performance of broilers vaccinated with the LaSota Newcastle Vaccine South African. J. Anim. Sci. 37(2): 74-80. https://doi.org/10.4314/sajas.v37i2.4030

- Basmacioglu H, Cabuk M, Ozkan S, Kocturk S, Oktay G, Ergul M (2009). Dietary vitamin E ( $\alpha$-tocopheryl acetate) and organic selenium supplementation: Performance and antioxidant status of broilers fed n-3 PUFA-enriched feeds. South African J. Anim. Sci. 39 :(4).

-Bou R, Guardiola F, Tres A, Barroeta AC, Codony R (2004). Effect of dietary fish oil, alpha-tocopherl acetate, and zinc supplementation on the composition and consumer acceptability of chicken meat. Poult. Sci. 83:282-292. https://doi.org/10.1093/ps/83.2.282

- Calder PC (2001). Polyunsaturated fatty acid, inflammation, and immunity. Lipids. 36: 1007-1024. https://doi.org/10.1007/ s11745-001-0812-7

- Chang YH, Lee JE, Kwak HS (2010). Optimization of the Conditions for Removing Cholesterol from Cod Liver Oil by $\beta$-Cyclodextrin Cross linked with a dipic Acid.J. Am. Oil
- Chashnidel Y, Moravej H, Towhidi A, Asadi F, Zeinodini S (2010). Influence of different levels of n-3 supplemented (fish oil) diet on performance, carcass quality and fat status in broilers. Afr. J. Biotech. 9 (5):687-691. https://doi. org/10.5897/AJB09.818

- Cherian G, Sim J (1992). Preferential accumulation of n-3 fatty acids in the brain of chicks from eggs enriched with n-3 fatty acids. Poult. Sci. 71: 1658-1668. https://doi.org/10.3382/ ps.0711658

-Dewailly E, Blanchet C, Lemieux S, Sauve L, Gingras S, Ayotte P, Holub BJ (2001). N-3 fatty acids and cardiovascular disease risk factors among the Inuit of Nunavik. Am. J. Clin. Nutr. 74: 464-473.

- Dos Santos TT, Corzo A, McDaniel CD, Torres Filho RA, Araujo LF (2010). Influence of in ovo inoculation with various nutrients and egg size on broiler performance. J.App. Poult. 19: 1-12. https://doi.org/10.3382/japr.2009-00038

- Fossati P, Prencipe L (1982). Serum triglycerides determined calorimetrically with an enzyme that produces hydrogen peroxide. Clin. Chem. 28: 2077-2080.

- Foye OT, Uni Z, Ferket PR (2006). Effect of in ovo feeding egg white protein, $\beta$-hydroxy- $\beta$-methylbutyrate, and carbohydrates on glycogen status and neonatal growth of turkeys. Poult. Sci. 85: 1185-1192. https://doi.org/10.1093/ ps/85.7.1185

- Gore AB, Qureshi MA (1997). Enhancement of humoral and cellular immunity by vitamin $\mathrm{E}$ after embryonic exposure. Poult. Sci.76: 984-991.https://doi.org/10.1093/ps/76.7.984

- Guillen MD, Carton I, Goicoechea E, Uriarte PS (2008). Characterization of cod liver oil by spectroscopic techniques. New approaches for the determination of compositional parameters, acyl groups, and cholesterol from $1 \mathrm{H}$ nuclear magnetic resonance and Fourier transform infrared spectral data, J. Agric. Food Chem. 56: 9072-9079. https://doi. org/10.1021/jf801834j

- Heird WC, Lapillonne A (2005). The role of essential fatty acids in development. Annu. Rev. Nutr. 25: 549-571. https://doi. org/10.1146/annurev.nutr.24.012003.132254

- Hunkar T, Aktan F, Ceylan A, Karasu C (2002). Effects of cod liver oil on tissue antioxidant pathways in normal and streptozotocin - diabetic rats. Cell Biochemistry and Function. 20: 297-302. https://doi.org/10.1002/cbf.977

-Ipek A, Sahan U, Yilmas B (2004). The effect of in ovo ascorbic acid and glucose injection in broiler breeder eggs on hatchability and chick weight. Euro. Poult. Sci. 68(3): 132135.

-Jaffer MJ (2010). Effect of using local fishmeal (Liza Abu) as protein concentration in broiler diets. Int. J. Poult. Sci. 9 (12): 1097-1099. https://doi.org/10.3923/ijps.2010.1097.1099

-Jessica ER (2001). Effect of omega-3 fatty acid on immunity, inflammation, cancerous cells. J. Immunol. 70: 115-125.

-Kehn P, Fernanetes G (2001). The importance of omega-3 fatty acids in the attenuation of immune mediated diseases. J. Clin. Immunol. 21. Abstr.

- Kidd MT (2004). Nutritional modulation of immune function in broiler. Poult. Sci. 83: 650-657. https://doi.org/10.1093/ ps/83.4.650

- Kidd MT, McDaniel CD, Peebles ED, Barber SJ, Corzo A, Branton SL, Woodworth JC (2005). Breeder hen dietary L-carnitine affects progeny carcass traits. Br. Poult. Sci. 46: 91-103. https://doi.org/10.1080/00071660400024027 
-Klasing KC (1998). Nutritional Modulation of resistance to infectious diseases. Poult. Sci. 77(80): 1119-1125. https:// doi.org/10.1093/ps/77.8.1119

-Koreleski J, Switakiewicz S (2006). The influence of dietary fish oil and vitamin $\mathrm{E}$ on the fatty acid profile and oxidative stability of frozen stored chicken breast meat. J. Anim. Feed Sci. 15: 631-640. https://doi.org/10.22358/jafs/66932/2006

- Leaf A, Weber PC (1988). Cardiovascular effects of n-3 fatty acids. N. Engl. J. Med. 318: 549-557. https://doi. org/10.1056/NEJM198803033180905

-Lopes KLAM, Pedroso AA, Leandro NSM, Stringhini JH, Barbosa CE (2006). Glutamine in ovo inoculation effect at the starter performance of broilers. Braz. J. Avian Sci. Camp. 8:103.

- Manilla H, Husveth AF, Nemeth K (1999). Effects of dietary fat origin on the performance of broiler chickens and composition of selected tissues. Acta. Agraria. Kaposvariensis. 3: 47-57.

-McGruder BM, Zhai W, Keralapurath MM, Bennett LW, Gerard PD, Peebles ED (2011a). Effects of in ovo injection of electrolyte solutions on broiler embryogenesis and posthatch performance. Poult. Sci. 90: 1058-1066. https://doi. org/10.3382/ps.2010-00893

- Moran E, JR T (2007). Nutrition of the developing embryo and hatchling. Poult. Sci. 86: 1043-1049. https://doi. org/10.1093/ps/86.5.1043

- National Research Council (1994). Nutrient Requirement for Poultry. 9th revised, Washington DC, National Academy Press PP.19-34.

- Noble RC, Cocchi M (1990). Lipid metabolism and the neonatal chicken. Prog. Lipid Res. 29: 107-140. https://doi. org/10.1016/0163-7827(90)90014-C

- Pamela CC, Richard AH, Denise RF (2009). Cholesterol and Steroid Metabolism. Biochemistry Lippincott's Illustrated Reviews. ed 4th Edition. Lippincott's Williams and Wilkins. Pp: 217-242.

- Pike IH (1999). The role of long chain omega-3 polyunsaturated fatty acids in animal feeding. Ifoma Tec. Bull. 3:1- 40.

- Prickeet JD, Robinson DR, Dloch KJ (1982). Enhanced production of $\mathrm{IgG}$ and $\mathrm{IgE}$ antibodies associated with a diet enriched in eicosapentaenoic asid. Immunol. 46: 819-826.

- Roy R, Singh S, Pujari S (2008). Dietary Role of Omega-3 Polyunsaturated fatty acid (PUFA): A study with Growing Chicks, Gallus domestics. Int. J. Poult. Sci. 7(4): 360-367. https://doi.org/10.3923/ijps.2008.360.367

- Safamerher A, Aghaei N, Mehannavaz Y (2008). The influence of different levels of dietary fish oil on the performance, carcass traits and blood parameters of broilers chickens. Res. J. Biol. Sci. 3(10): 1202-1207.

- Sakr WM (2007). Enhancement of humoral and cellular immunity of broiler chicks vaccinated with Newcastle disease by the dietary supplementation of fish oil. M.Sc. thesis, University of Basrah.

- Saleh H, Rahimi SH, Karimi Torshizi MA (2009).The effect of diet that contained fish oil on performance, serum parameters, the immune system and the fatty acid composition of meat in broilers. Int. J. Vet. Res. 3(2): 69-75.

-Salih GE (2009). Effects of inclusion of local disposed roasted fish meal on the performance and carcass characteristics of broiler. Egypt Poult. Sci. 29: 735-745.

- Schaal TP (2008). The effect of in ovo feeding of fatty acids and antioxidant on broiler chicken hatchability and chick tissue lipids. Honors College. Oregon State University.
Advances in Animal and Veterinary Sciences

-Selim SA, Gaafer KM, El-ballal SS (2012). Influence of in ovo administration with vitamin $\mathrm{E}$ and Ascorbic acid on the performance of Muscovy ducks. Emir. J. Food Agric. 24(3): 264-271.

-Shaikh SR, Edidin M (2006). Polyunsaturated fatty acids, membrane organization, $\mathrm{T}$ cells, and antigen presentation. Am. J. Clin. Nutr. 84: 1277-1289.

-Smirnov A, Tako E, Ferket PR, Uni Z (2006). Mucin gene expression and mucin content in the chicken intestinal goblet cells are affected by in ovo feeding of carbohydrates. Poult. Sci. 85: 669-673. https://doi.org/10.1093/ps/85.4.669

- Snedecor GW, Cochran WG (1980). Statistical methods. Iowa State University, press. Iowa.

- SPSS (1999). Statistical Package of Social Science. Ver.11. Application Guide. Copy right by SPSS Inc. USA.

- Sultan SIA (2005). Effect of dietary fish oil on production traits and lipid composition of laying hens, Int. J. Poult. Sci. 4 (8): 586-588. https://doi.org/10.3923/ijps.2005.586.588

-Tako E, Ferket PR, Uni Z (2004). Effects of in ovo Feeding of Carbohydrates and $\beta$-Hydroxy- $\beta$-Methylbutyrate on the Development of Chicken Intestine. Poult. Sci. 83: 20232028. https://doi.org/10.1093/ps/83.12.2023

-Torki M, Golian A, Arshami J, Tavakkoli J (2000). Effect of dietary fat source and fatty acid composition on immune responses of male growing broiler chicks. PSA Place of Meeting.

-Uni, Z. and P.R. Ferket. 2004. Methods for early nutrition and their potential.World's Poult. Sci.J.60:101-111. https://doi. org/10.1079/WPS20038

-Uni Z, Ferket PR, Tako E, Kedar O (2005). In Ovo Feeding Improves Energy Status of Late-Term Chicken Embryos. Poult. Sci. 84:764-770. https://doi.org/10.1093/ps/84.5.764

-Wang YW, Field CJ, Sim JS (2000). Dietary poly unsaturated fatty acids alter lymphocyte subset proportion and proliferation, serum immunoglobulin $\mathrm{G}$ concentration, and immune tissue development in chicks. Poult. Sci. 79: 17411748. https://doi.org/10.1093/ps/79.12.1741

-Wotton IDP (1964). Micro analysis in medical biochemistry. 4th Ed. J. and A. Churchill Ltd. London PP: 71-73.

-Yegani M, Korver DR (2008). Factor affecting intestinal health in poultry. Poult. Sci. 87: 2052-2063. https://doi. org/10.3382/ps.2008-00091

-Zhai W, Neuman S, Latour MA, Hester PY (2008). The effect of in ovo injection of L-carnitine on hatchability of White Leghorns. Poult. Sci. 87: 569-572. https://doi.org/10.3382/ ps.2007-00348

-Zhang HX, Guo Y, Yuan J (2005). Conjugated linoleic acid enhanced the immune function in broiler chicks. Br. J. Nutr. 94: 746-752. https://doi.org/10.1079/BJN20051482 